\title{
Sinking Deltas
}

James P.M. Syvitski ${ }^{l}$, Albert J. Kettner ${ }^{l}$, Irina Overeem ${ }^{l}$, Eric W.H.Hutton ${ }^{l}$, Mark T. Hannon ${ }^{l}, G$. Robert Brakenridge ${ }^{2}$, John Day ${ }^{3}$, Charles Vörösmarty ${ }^{4}$, Yoshiki Saito $^{5}$, Liviu Giosan ${ }^{6}$, Robert J. Nicholls $^{7}$

${ }^{I}$ CSDMS Integration Facility, INSTAAR, University of Colorado, Boulder CO, 80309-0545

${ }^{2}$ Dartmouth Flood Observatory, Dartmouth College, Hanover, NH 03755

${ }^{3}$ Dept. of Oceanography and Coastal Sciences, Louisiana State University, Baton Rouge, LA 70803

${ }^{4}$ Dept. of Civil Engineering, City College of New York, City University of New York, NY 10035

${ }^{5}$ Geological Survey of Japan, AIST, Tsukuba 305-8567, Japan

${ }^{6}$ Woods Hole Oceanographic Institution, Woods Hole, MA 02543

${ }^{7}$ School of Civil Engineering and the Environment and Tyndall Centre for Climate Change

Research, University of Southampton, SO17 IBJ UK

\begin{abstract}
The world's population living on low-lying deltas is increasingly vulnerable to flooding, whether from intense rainfall, rivers or from hurricane-induced storm surges. High-resolution SRTM and MODIS satellite data along with geo-referenced historical map analysis allows quantification of the extent of low-lying delta areas and the role of humans in contributing to their vulnerability. Thirty-three major deltas collectively include $\sim 26,000 \mathrm{~km}^{2}$ of area below local mean sea level and $\sim 96,000 \mathrm{~km}^{2}$ of vulnerable area below $2 \mathrm{~m}$ a.s.l. The vulnerable areas may increase by $50 \%$ under projected $21^{\text {st }}$ Century eustatic sea level rise, a conservative estimate given the current trends in the reduction in sedimentary deposits forming on the surface of these deltas. Analysis of river sediment load and delta topographical data show that these densely populated, intensively farmed landforms, that often host key economic structures, have been destabilized by human-induced accelerated sediment compaction from water, oil and gas mining, by reduction of incoming sediment from upstream dams and reservoirs, and from floodplain engineering.
\end{abstract}

\section{Introduction}

Close to 0.5 billion people live on, or near, world deltas, inclusively in many mega-cities $(1,2)$. Ten countries (China, India, Bangladesh, Vietnam, Indonesia, Japan, Egypt, USA, Thailand, and the Philippines) account for $73 \%$ of the people that live in the world's coastal zone, defined as within $10 \mathrm{~m}$ a.s.l. (3). $20^{\text {th }}$-century catchment developments and population and economic growth within subsiding deltas have placed these environments and their populations under a growing risk of coastal flooding, wetland loss, shoreline retreat, and loss of infrastructure $(4,5)$. It is estimated that more than 10 million people per year experience flooding due to storm surges, and most of these people are living on Asian deltas (6). Using new, globally-consistent and highresolution topographic data, three hypotheses are tested: 1) deltas are rapidly sinking, often to below local sea level, 2) the lack of sediment getting to delta floodplains is the main reason so many deltas are sinking, and 3) human activities are largely responsible for the present vulnerability of deltas. For a representative suite of deltas, Shuttle Radar Topography Mission (SRTM) data are applied to evaluate delta topography, in relation to mean sea level. Historical maps are geo-referenced against detailed topographic data to map morphodynamic patterns and quantify how rivers once flowed through deltas. Visible and near-infrared Moderate Resolution Imaging Spectroradiometer (MODIS) satellite images are used to assess flooding in modern deltas and investigate whether such flooding is mainly from river runoff or instead from coastal storm surges, and whether present river suspended load is sufficient to maintain delta plain aggradation and stability. 


\section{Background}

Change in the position of a delta's surface relative to local mean sea level $\left(\Delta_{R S L}\right)$ is from the contribution of three components:

1) Changes to the volume of the global ocean (Eustasy, E) over time, as influenced by fluctuations in the storage of terrestrial water (e.g. glaciers, ice sheets, groundwater, lakes, and reservoirs), and fluctuations in temperature of the ocean's surface waters (7). Today $E$ contributes $\approx 1.8$ to $3 \mathrm{~mm} / \mathrm{y}$ to $\Delta_{R S L}(7,8)$ largely under the anthropogenic influence of global warming. The IPCC projected that sea level will likely rise by $21-71 \mathrm{~cm}$ by the year 2070 with a best estimate of $44 \mathrm{~cm} \mathrm{(7)} \mathrm{but} \mathrm{there} \mathrm{is} \mathrm{ongoing} \mathrm{discussion} \mathrm{on} \mathrm{the} \mathrm{dynamic} \mathrm{response} \mathrm{of} \mathrm{the} \mathrm{major} \mathrm{ice} \mathrm{sheets} \mathrm{that}$ could potentially contribute even more water over this period.

2) Vertical movements of the land surface $(M)$, as influenced by hydro-isostasy related to sea level fluctuation, loading due to the weight of delta deposits, glacio-isostasy related to the growth or shrinkage of nearby ice masses (9), tectonics, and deep-seated thermal subsidence $(5,10,11$, 12). Tectonic subsidence along faults in the Mississippi delta contributes $5 \pm 2 \mathrm{~mm} / \mathrm{y}$ to its $\Delta_{R S L}$ (13). The Earth's crust takes thousands of years to relax from loading changes (14) and displacements extend over a region much larger than the direct area of the load change. The six sediment lobes of the Holocene Mississippi delta, each weigh between 135 and 847 billion metric tons, and contribute up to $5 \mathrm{~mm} / \mathrm{y}$ to its $\Delta_{R S L}(5,15)$. While important, seldom are $M$ contributions to a delta's $\Delta_{R S L}$ calculated, particularly with all its varied terms.

3) Changes to the sedimentary volume of delta deposits through Natural Compaction $\left(C_{n}\right)$, Accelerated Compaction $\left(C_{A}\right)$, and Aggradation $(A) . C_{n}$ involves natural changes in the void space within delta sediment (e.g. due to dewatering of soils and prodelta mud, grain-packing realignment, and natural organic matter oxidation) $(16,17) . C_{n}$ typically contributes $\leq 3 \mathrm{~mm} / \mathrm{y}$ to $\Delta_{R S L}(5) . C_{A}$ is the anthropogenic contribution to this volume change, from subsurface mining of oil, gas or groundwater, soil drainage and oxidation. The effects may be localized but can be dramatic, e.g.: i) Yangtze: $C_{A}=28 \mathrm{~mm} / \mathrm{y}$ before controls on groundwater withdrawal came into effect circa 1965 (18), ii) Mississippi near New Orleans: $C_{A}=5$ to $25 \mathrm{~mm} / \mathrm{y}(19)$, when organic soils are drained and oxidized (20), and gas is mined (21), iii) Niger: $C_{A}=25$ to $125 \mathrm{~mm} / \mathrm{y}$ from petroleum mining (22), iv) Chao Phraya: $C_{A}=50$ to $150 \mathrm{~mm} / \mathrm{y}$ from groundwater withdrawal (23), and v) Po: $C_{A}=60 \mathrm{~mm} / \mathrm{y}$ during the peak of methane mining (24). The Po Delta has subsided 3.7 $\mathrm{m}$ in the $20^{\text {th }}$ Century, of which $81 \%$ is attributed to methane mining. After the cessation of methane extraction, the rate slowed to $<25 \mathrm{~mm} / \mathrm{y}$ by 1970 (25), and by the 1990 's the subsidence rate was $\leq 4 \mathrm{~mm} / \mathrm{y}(26)$.

Sediment input to deltas is highly dynamic and occurs as a hierarchy of pulses over a wide range of temporal and spatial scales (27). Aggradation $(A)$ is the addition of volume from sediment that is delivered to and retained on the subaerial delta as new sedimentary layers. $A$ has rates varying from $1-50 \mathrm{~mm} / \mathrm{y}$ (Table 1). Flooding occurs from river overbanking, or local surface runoff related to intense rainfall, or from coastal storm surges. Most river floods bring high amounts of suspended load to a delta's surface, although upstream dam interception of river-borne sediment may leave a river with relatively clean river water, flowing with reduced flood magnitudes. Flooding from the ocean may contribute turbid water from tide or wave resuspension. For example, hurricane-generated storm surges add sediment to the outer portions of the Mississippi Delta $(28,29)$, whereas artificial levees confine the Mississippi River and prohibit river flooding on its delta plain.

Humans have often reduced the number of naturally occurring distributary channels, fixed their 
location to support low-flow navigation, and protected populated areas from flooding by levees (1). Aggradation may thus be limited to within the distributary channels. On the Po Delta, artificial levees do not allow for upstream flood waves to overbank and penetrate the delta plain, consequently within-channel aggradation ranges from 20 to $>60 \mathrm{~mm} / \mathrm{y}(30)$. Levees will eventually cause super-elevation of the riverbed above the surrounding floodplain. If the distributary channels are free to migrate across the delta plain, or episodically switch their position, then the delta surface builds up as a series of fluvial deposits. In China, controlled flooding has even been used to raise land via sedimentation in the Yellow River Delta (31).

Sediment input to deltas has been reduced or eliminated at all scales (27). Delivery is often through distributary channels engineered to bypass and not interact with the delta plain (Table 1). The consequence is much reduced levels of delta plain aggradation. Lack of appreciation of the broad range of scales over which deltaic processes operate may lead to erroneous conclusions about how deltas function $(32,29,17)$.

Often field measurements do not separate $M, C_{n}, C_{A}$ and $A$ as unique contributions to a delta's overall Subsidence $(S)$ (relative sinking of the land surface). Large deltas have areas on the order of $10^{4}$ to $>10^{5} \mathrm{~km}^{2}$ and consequently $S$ is spatially variable, depending on a location's unique load and compaction history. Seldom is an area-integrated $S$ calculated. In one rare study, involving the Mississippi Delta, three independent data sources (Synthetic Aperture Radar, GPS geodesy, and leveling) identified an area-averaged $S$ of 5 to $6 \mathrm{~mm} / \mathrm{y}$. This survey included parts of New Orleans that have subsided $25 \mathrm{~mm} / \mathrm{y}$ over the last 150 years when major drainage and levee construction began after 1850 (19).

\section{Methodology}

Thirty-three representative deltas (Supplementary Figure 1) were examined using SRTM altimetry (see Table 1, Figs. 1-4). The altimetry has a vertical root mean square error between 1.1 to $1.6 \mathrm{~m}$ in lowland areas $(15,33)$. The horizontal footprint of a SRTM pixel is either 1-arc or 3arc seconds. Deltas were examined for the extent and location of areas near or below sea level $(<0$ $\mathrm{m}$ and $<2 \mathrm{~m}$ a.s.1.). We used the high-end sea level rise estimates ( $>0.7-1.1 \mathrm{~m})$ of suites of climate model scenarios (7) to estimate increases in vulnerable delta lowlands $(<3 \mathrm{~m}$ a.s.l). MODIS imagery at between 250 and $500 \mathrm{~m}$ resolution was used to map floodwater extent on deltas and indicate whether the water was rich in suspended sediment (Fig. 3, Table1, Supplementary Figures 3-8). Eighty-six historical maps (published between 1760 and 1922) of the selected deltas were analyzed for the location and number of distributary channels (Fig. 4, Table 1, Supplementary Figure 10).

Early-20 $0^{\text {th }}$ Century Aggradation rates (Table 1) are determined from a database of gauged river sediment loads that once reached the deltas, as measured before the proliferation of upstream dams $(30,34,35,23)$ and modeling of sediment retention on a delta per unit area (1). Small and steep gradient rivers retain little sediment as they cross their delta plain; retention rates are in the 10 to $20 \%$ range. Larger deltas with numerous distributary channels have a larger retention rate of 50 to $60 \% .21^{\text {st }}$ Century Aggradation rates (Table 1) use the previous estimates and adjust for Late $20^{\text {th }}$ Century sediment reduction due to reservoir trapping and engineering control on river flooding. Most deltas saw their incoming sediment loads substantially reduced during the Late $20^{\text {th }}$ Century, half by more than $50 \%$ (Table 1 ).

Subsidence values (Table 1) are from literature sources (e.g. 23, 36) and the Permanent Service for Mean Sea Level (PSMSL), hosted at the Proudman Oceanographic Laboratory (POL) (15). A word of caution on Subsidence rates: rates in the literature often are maximum rates within a delta, and not area integrated, whereas our calculated Aggradation rates are area-integrated rates. 
Subsurface mining activity is from literature sources (e.g. 5, 37). Consequently, Subsidence rate data carries significant uncertainty and prohibits making more precise predictions of the future trends of delta surface positions.

\section{Results}

SRTM data reveal deltas with significant areas (100's to 10,000 's $\mathrm{km}^{2}$ ) of vulnerable lowlands at elevation $<2 \mathrm{~m}$ of mean sea level (Table 1), and thus susceptible to river floods and inundation from storm surges, especially those deltas subject to tropical storms (Supplementary Figure 11). Many deltas have large areas below mean sea level (Fig. 1) that are protected from ambient coastal inundation via natural barriers (e.g. beach ridges and dunes), engineered structures, or some combination (e.g. Po, Vistula, Nile, and the Yellow/Huanghe). Thirty-three deltas have a combined area of $26,000 \mathrm{~km}^{2}$ below mean sea level. The Pearl delta, China, and the Mekong delta, Vietnam, both inhabitated by millions of people and exposed to typhoons, seem particularly vulnerable with much of their surface area below mean sea level, and limited coastal barrier protection (Fig. 2). The Irrawaddy delta shows extensive lowland, and it is therefore understandable how a significant coastal surge, such as associated with Cyclone Nargis, could so easily inundate large parts of this delta in 2008 (Fig. 3).

$21^{\text {st }}$ Century Aggradation rates have substantively decreased (Table 1), or been nearly or completely eliminated (e.g. Chao Phraya, Colorado, Nile, Po, Tone, Vistula, Yangtze, and the Yellow River deltas). For a few deltas, Aggradation has changed little over the $20^{\text {th }}$ century, and remains in balance with, or exceeds Subsidence or Relative Sea Level Rise (Table 1: e.g. Amazon, Congo, Fly, Orinoco). Some deltas have seen their Aggradation rate decreased with engineering, but the rate still exceeds Subsidence (Table 1: Amur, Brahmani, Danube, Han, Limpopo, and the Mahanadi). This condition offers a level of protection from storm surges. However, even for a delta, such as the Danube, where subsidence is fully compensated by local tectonic uplift (38), the reduction in sediment load led to a decrease in aggradation, coastal erosion and increased inundation from sea surges (39).

Other deltas experience a Subsidence rate much greater than even early $20^{\text {th }}$ Century Aggradation (Table 1: Chao Phraya, Ganges, Irrawaddy, Mahakam, Mekong, Mississippi, Niger, Nile, Pearl, Po, Sao Francisco, Tigris, and the Yangtze). For these deltas, Accelerated Compaction brought on by human activities is an overwhelming reason why the delta is sinking. For other deltas, a reduced Aggradation rate is the overwhelming reason why the delta is sinking, e.g. Colorado, Godavari, Indus, Krishna, Magdalena, Parana, Rhone, Tone, and the Vistula. Yet many deltas suffer both from Accelerated Compaction and greatly reduced Aggradation rates, e.g. Chao Phraya, Colorado, Krishna, Nile, Pearl, Po, Rhone, Sao Francisco, Yangtze and the Yellow (Table 1).

Based on these data, hypothesis (1) is accepted. Many (71\%) of the representative deltas are indeed sinking. Hypothesis (2) is modified to allow for the equally important impact of Accelerated Compaction on delta sinking, as well as the greatly reduced Aggradation, from both a decrease in the incoming sediment load, and from levee control on delta plain flooding. Fifty percent of the sinking deltas are influenced by both components. Hypothesis (3) is also accepted; local human activities are largely responsible for present vulnerability of deltas.

Daily satellite imagery has been collected only for the last decade, too short an interval to confirm the full extent of flooded areas on deltas. However, over the last decade, half of the represented deltas experienced coastal inundation from surges (Table 1), with the Mahanadi, Yellow, Mississippi, Krishna, Tigris, Indus, and Irrawaddy of note. Many deltas experienced floods from rivers overbanking their levees (Table 1), with the Parana, Vistula, Chao Phraya, Ganges, Pearl, 
Danube, Krishna, Rhone, Mekong, and the Brahmani of note. Many deltas were partially flooded from intense rainfall and its associated local runoff within the delta (Table 1), with the most susceptible deltas being the Mississippi, Mahanadi, Krishna, Mekong, Brahmani, and the Ganges. In 2007/08 alone, the following deltas had substantial areas flooded: Ganges, Mekong (Fig. 3), Irrawaddy (Fig. 3), Chao Phraya, Brahmani, Mahanadi, Krishna, and Godavari (Supplementary Figures 2-8), with $>100,000$ lives lost and more than a million habitants temporarily displaced. Satellite imagery further reveals that often the flooding is not contributing much sediment accumulation, both for reasons of upstream reservoir trapping and from in place levees. The imagery thus qualitatively supports the reduced $21^{\text {st }}$ Century Aggradation rates in Table 1 . Two exceptions are provided in Fig. 3. The Mekong, from river-borne sediment, and the Irrawaddy, from marine-borne sediment, both saw much sediment added to their delta surface.

Another reason why recent Aggradation rates are so low is the reduction in the number and mobility of natural distributary channels. Thirteen of the major deltas saw their distributary channel number decrease, some markedly (Table 1), with the Magdalena, Nile, Vistula, Yellow and the Indus showing all $\sim 70-80 \%$ reductions. The Indus delta provides a classic example of how through the nineteenth century, and earlier (40), river distributary channels migrated across the delta surface (Fig. 4). SRTM topographic data reveal the lobate sediment deposits from the ancient crevasse splay and paleo-river channels (Fig. 4a). Distributary channels were numerous, and successive surveys show channels to have been mobile (Fig. 4b). To better use precious water resources on the Indus floodplain, an elaborate $20^{\text {th }}$ Century irrigation system was put in place (Fig. 4c) that captured much of the water, sediment and nutrients. Today very little water and sediment makes it to the delta plain through its remaining connection to the ocean $(1,41$, Table 1). Channels on deltas are often stabilized and provide a perceived sense of safety of riverside towns (5). In the Nile delta, the sediment escaping the upstream Aswan dam, which is already less than $2 \%$ of the original sediment load, is almost completely trapped by a dense network of irrigation channels in the delta (42). The remaining five Po distributary channels still trap $16 \%$ of the sediment delivered to the delta, but the sedimentation occurs strictly within the distributary channels themselves and not on the surrounding flood plains which are often well below sea level (30). Ironically, delta-wide aggradation rates may have reduced, but local differential relief may result in increased flood risk.

\section{Summary \& Conclusions}

Humans are fundamentally altering the functioning of deltas at the global scale. Humans have altered deltaic coastlines through coastline occupation and stabilization. But behind these coastal structures the analyzed major deltas show a combined vulnerable area of $96,000 \mathrm{~km}^{2}$ near local sea level. This area would increase to $\sim 143,000 \mathrm{~km}^{2}$ over the $21^{\text {st }}$ Century if global sea level continues to rise rapidly (8) and we consider vulnerable delta lowlands to be $<3 \mathrm{~m}$ a.s.l.

Furthermore, these lowlands are likely to expand from both reduced Aggradation and Accelerated Compaction due to hydrocarbon and water withdrawal $(36,37)$. Humans have engineered most of the natural river discharge delivered to the coast across the delta plain, through up-basin sediment capture and flood wave mitigation. They have stabilized many delta distributary channels and reduced their number, thereby altering the sediment pathways to the coast. Human occupation and infrastructure development continues through the development of delta megacities and their expanding footprint. Without budgeting for the major human contribution to delta sinking, more and more of our world's wetlands will be drowned, while the threats to human activities within deltas will continue to grow.

Global-warming induced sea-level rise is adding to this bleak scenario. An additional immediate impact of global-warming will be changes in magnitude and frequency of hurricanes and 
cyclones $(43,44)$, and more intense precipitation events $(45)$. While humans have worked to master the everyday behavior of lowland rivers; they are less able to deal with the fury of extreme events that either cause extensive flooding or that can wash ashore ocean water, with surges 3 to $10 \mathrm{~m}$ above mean sea level. The management of delta systems faces a number of fundamental challenges, and the different components adding to the extent of vulnerable area must be precisely addressed if deltaic areas are not to substantially decline with disastrous consequences for the environment and delta residents. It remains alarming how often deltas flood, whether from hurricanes or storm fronts, from land or from sea; river and delta flooding already appears to be increasing and will likely increase in the coming century.

\section{References and Notes}

1. Syvitski, J.P.M., Saito, Y. Morphodynamics of Deltas under the Influence of Humans. Global Planet, Change 57, 261-282 (2007).

2. Woodroffe, C.D., Nicholls, R.J., Saito, Y., Chen, Z. \& Goodbred, S.L. Landscape variability and the response of Asian megadeltas to environmental change in Global Change and Integrated Coastal Management: the Asia-Pacific Region, Coastal Systems and Continental Margins, Vol. 10, N. Harvey, Ed., (Springer, NY, 2006), pp. 277-314.

3. Sanchez-Rodriguez, R. et al., Introduction to the "Global Environmental Change, Natural Disasters, Vulnerability and their implications for Human Security in Coastal Urban Areas" Issue IHDP Update 2, 4-5 (2007).

4. Nicholls, R.J. et al., Coastal systems and low-lying areas. in Climate Change 2007: Impacts, Adaptation and Vulnerability. Contribution of Working Group II to the Fourth Assessment Report of the Intergovermental Panel on Climate Change. M.L. Parry, O.F. Canziani, J.P. Palutikof, P. van der Linden, C.E. Hanson, Eds. (Cambridge University Press, UK, 2007) pp.315-357.

5. Syvitski, J.P.M. Deltas at risk. Sustainability Science 3, 23-32 (2008).

6. Nicholls, R.J. Coastal flooding and wetland loss in the $21^{\text {st }}$ century: changes under the SRES climate and socio-economic scenarios. Global Environ. Change 14, 69-86 (2004).

7. Bindoff, N.L. et al. Observations: Oceanic Climate Change and Sea Level. in Climate Change 2007: The Physical Science Basis. Contribution of Working Group I to the Fourth Assessment Report of the Intergovernmental Panel on Climate Change, S. Solomon, et al. Eds. (Cambridge University Press, New York, 2007).

8. Church, J.A., White, N.J. A $20^{\text {th }}$ century acceleration in global sea-level rise. Geophysical Research Letters 33, L01602. doi:10.1029/2005GL024826 (2006).

9. Milne, G.A., Mitrovica, J.X. Searching for eustasy in deglacial sea-level histories. Quaternary Science Reviews. doi:10.1016/j.quascirev.2008.08.018 (2008).

10. Jouet, G, Hutton, E.W.H., Syvitski, J.P.M., Rabineau, M. \& Berné, S. Modeling the isostatic effects of sealevel fluctuations on the Gulf of Lions Computers \& Geosciences 34, 1338-1357 (2008).

11. Blum, M.D. Tomkin, J.H., Purcell, A. Lancaster, R.R. Ups and downs of the Mississippi Delta. Geology 36, 675-678 (2008).

12. Ivins, E.R., Dokka, R.K. \& Blom, R.G. Post-glacial sediment load and subsidence, in coastal Louisiana. Geophys. Res. Lett. 34 doi:10.1029/2007GL030003 (2007). 
13. Dokka, R.K., Sella, G.F. \& Dixon, D.H. Tectonic control of subsidence and southward displacement of southeast Louisiana with respect to stable North America. Geophys. Res. Lett. 33 doi:10.1029/2006GL027250 (2006).

14. Hutton E.W.H. \& Syvitski, J.P.M. SedFlux2.0: New advances in the seafloor evolution and stratigraphic modular modeling system. Computers \& Geosciences 34, 1319-1337 (2008).

15. Supplementary materials and methods are available online.

16. Meckel, T. A., Ten Brink, U. S. \& Williams, S. J. Sediment compaction rates and subsidence in deltaic plains: numerical constraints and stratigraphic influences. Basin Research 19, 19-31 (2007).

17. Törnqvist, T. E. et al. Mississippi Delta subsidence primarily caused by compaction of Holocene strata. Nature Geoscience 1, 173-176 (2008).

18. Han M, Hou J, Wu L. Potential impacts of sea level rise on China's coastal environment and cities: a national assessment. J. Coastal Res. 14, 79-90 (1995).

19. Dixon, T.H. Earth Scientists and Public Policy: Have we failed New Orleans? Eos Trans. $A G U$ 89, 96 (2008)

20. Stephens, J.C., Allen, L.H., Chen, E. Organic soil subsidence. in Man-Induced Land Subsidence, T.L. Holzer Ed., Rev. Eng. Geol. Ser. VI, 107-122 (1984).

21. Morton, R.A., Bernier. J.C., Barras, J.A. \& Ferina, N.F. Rapid subsidence and historical wetland loss in the Mississippi delta plain: likely causes and future implications. USGS Open File Report 2005-1216, 124 pp. (2005).

22. Abam, T.K.S. Regional hydrological research perspective in the Niger Delta Hydrological Sciences 46, 13-25 (2001).

23. Saito Y., Chaimanee N., Jarupongsakul, T., \& Syvitski, J.P.M. Shrinking megadeltas in Asia: Sea-level rise and sediment reduction impacts from case study of the Chao Phraya delta. Inprint Newsletter of the IGBP/IHDP Land Ocean Interaction in the Coastal Zone 2007/2, 3-9 (2007).

24. Caputo, M., Pieri, L., Unghendoli, M. Geometric investigation of the subsidence in the Po Delta. Boll. Geofis. Teor. Appl. 14, 187-207 (1970).

25. Bondesan, M., Simeoni, U. Dinamica e analisi morfologica statistica dei litorali del delta del Po e alle foci dell'Adige e del Brenta. Mem. Sci. Geol. 36, 1-48 (1983).

26. Simeoni, U., Fontolan, G., Tessari, U. \& Corbau, C. Domains of spit evolution in the Goro area, Po Delta, Italy. Geomorphology 86, 332-348 (2007).

27. Day, J.W., Jr. et al. Restoration of the Mississippi Delta: Lessons from Hurricanes Katrina and Rita. Science 315, 1679-1684 (2007).

28. Turner, R.E., Swenson, E.M. Milan, C.S. \& Lee, J.M. Hurricane signals in salt marsh sediments: Inorganic sources and soil volume. Limnol. Oceanogr. 52, 1231-1238 (2007).

29. Turner, R.E. Baustian, J.J. Swenson, E.M. \& Spicer, J.S. Wetland Sedimentation from Hurricanes Katrina and Rita. Science 314, 449-452 (2006).

30. Syvitski, J.P.M., Kettner, A.J., Correggiari, A. \& Nelson, B.W. Distributary channels and their impact on sediment dispersal. Marine Geology 222-223, 75-94 (2005).

31. Yu, L. The Huanghe (Yellow) River: Recent changes and its countermeasures. Cont. Shelf Res. 26, 2281-2298 (2006). 
32. J.W. Day, Jr., et al. Pattern and process of land loss in the Mississippi Delta: A Spatial and Temporal Analysis of Wetland habitat change. Estuaries 23, 425-438 (2000).

33. Schumann, G. et al., Comparison of remotely sensed water stages from LiDAR, topographic contours and SRTM. ISPRS J. Photogrammetry \& Remote Sensing 63, 283-296 (2008).

34. Milliman, J.D. \& Syvitski, J.P.M. Geomorphic/tectonic control of sediment discharge to the ocean: The importance of small mountainous rivers. J. Geology 100, 525-544 (1992).

35. Syvitski, J.P.M. \& Milliman, J.D. Geology, geography and humans battle for dominance over the delivery of sediment to the coastal ocean. Geology 115, 1-19 (2007).

36. Roldolfo, K.S. \& Siringan, F.P. Global sea-level rise is recognised, but flooding from anthropogenic land subsidence is ignored around northern Manila Bay, Philippines. Disasters 30, 118-139 (2006).

37. Ericson, J.P., Vörösmarty, C.J., Dingman, S.L., Ward, L.G. \& Meybeck, M. Effective sealevel rise and deltas: causes of change and human dimension implications. Global Planet. Change 50, 63-82 (2006).

38. Giosan, L. et al., Young Danube delta documents stable Black Sea level since the middle Holocene: Morphodynamic, paleogeographic, and archaeological implications. Geology 34, 757-760 (2006).

39. Giosan, L., Bokuniewicz, H.J., Panin, N. \& Postolache, I. Longshore sediment transport pattern along the Romanian Danube delta coastJ. Coastal Res. 15, 859-871 (1999).

40. Holmes, D.A. The Recent History of the Indus. The Geog. J. 134, 367-382 (1968).

41. Giosan, L. et al. Recent morphodynamics of the Indus delta shore and shelf. Cont. Shelf Res. 26, 1668-1684 (2006).

42. Stanley, J.D. \& Warne, A.G. Nile delta in its destructive phase, J. Coastal Res. 14, 794-825 (1998).

43. Goldenberg, S.B. et al. The recent increase in Atlantic hurricane activity: causes and implications. Science 293. 474-479 (2001).

44. Holland, G., Webster, P. Heightened tropical cyclone activity in the North Atlantic: natural variability or climate trend? Phil. Trans. R. Soc. A doi:10.1098/rsta.2007.2083 (2007).

45. Lambert, F.H. Stine, A.R. Krakauer, N.Y. \& Chiang, J.C.H. How much will precipitation increase with global warming. EOS, Transactions of AGU, 89, 193-194 (2008).

\section{Acknowledgements:}

We thank the following organizations for their research funding: National Science Foundation (Cooperative Agreement 0621695), NASA (NNXOTAF2SG/P207124;

NNXOTAF28G/P207124), and the Office of Naval Research (N00014-04-1-0235). Many scientists have contributed to this effort, including Chris Paola (NCED), Scott Peckham (CSDMS), Won-Suk Kim (U. Illinois U-C), Joep Storms (Delft U. Tech), and Ilan Kelman (Norway). 
Table 1. Representative deltas analyzed using MODIS imagery, SRTM data, and ancillary data (see Methodology section and 15 for details). Commentary in the storm surge column is as follows: LP= little potential; $\mathrm{MP}=$ moderate potential; $\mathrm{SP}=$ significant potential). Net Subsidence (or Relative Sea Level Rise) rates are time variable, and provided ranges cover different times and areas of a delta, where known; question marks are for unknown estimates.

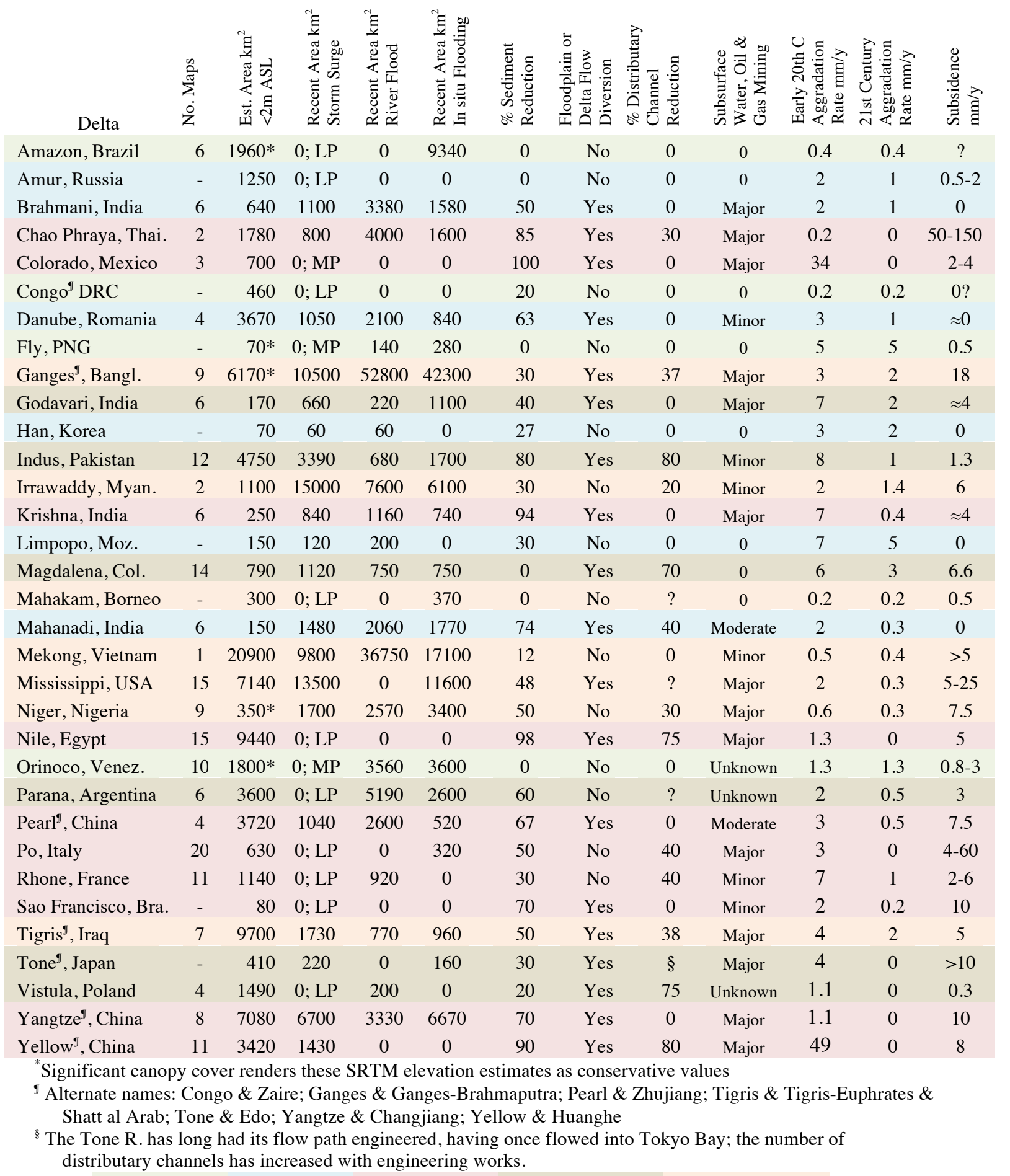

Color key $20^{\text {th }} A \approx 21^{\text {st }} A>S \quad 20^{\text {th }} A>21^{\text {st }} A>S \quad 20^{\text {th }} A>>21^{\text {st }} A<<S \quad 20^{\text {th }} A \gg>21^{\text {st }} A<S \quad 20^{\text {th }} A>21^{\text {st }} A<<S$ 


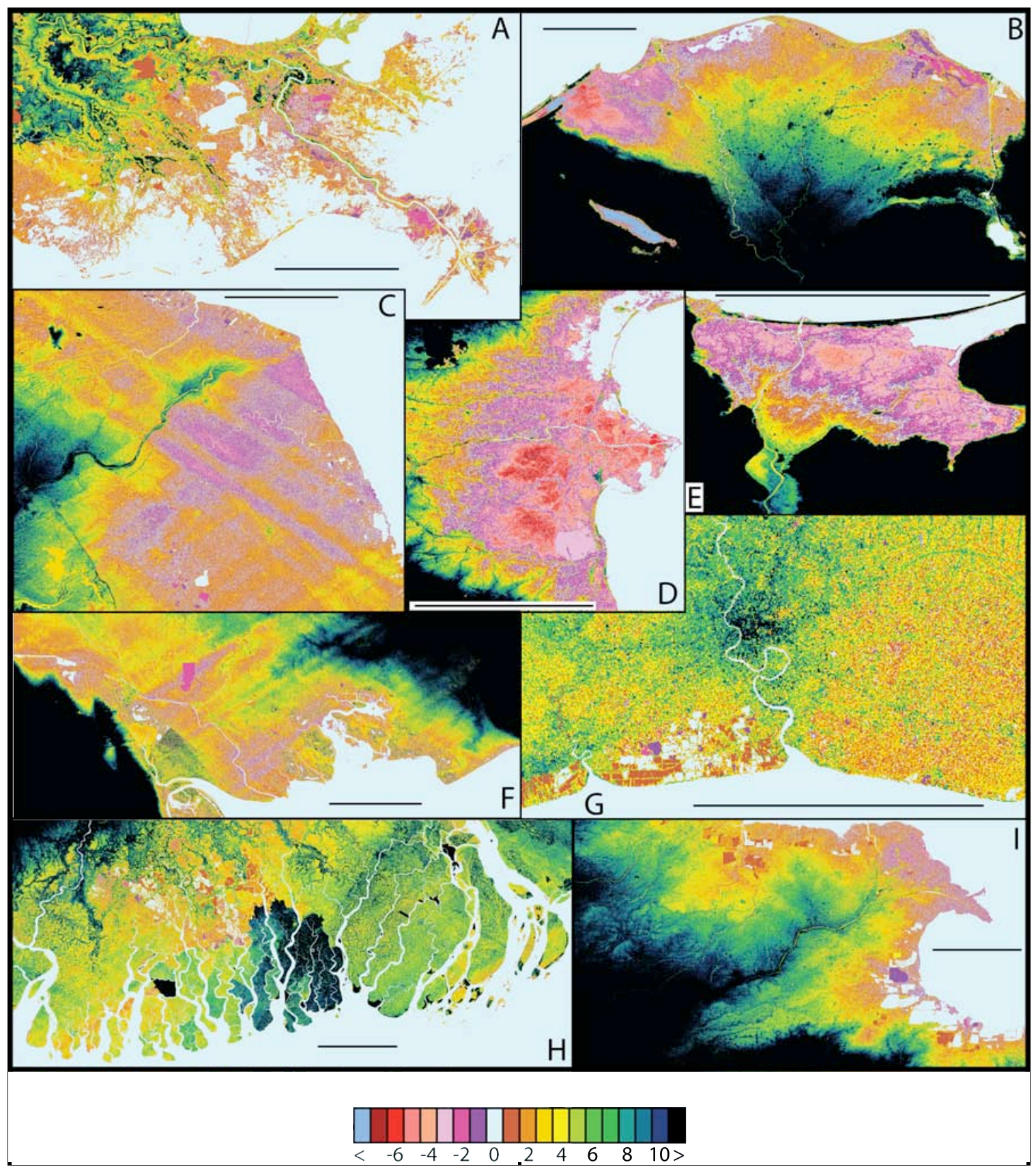

Figure 1: Nine representative deltas, displayed with Space Shuttle Radar (SRTM) altimetry, binned at $1 \mathrm{~m}$ vertical intervals, starting at sea level (light blue), then 1 color per $1 \mathrm{~m}$ interval, with colors cycled every $10 \mathrm{~m}$, to a height of $100 \mathrm{~m}$, then black. Topography below mean sea level is in shades of pink. A) Mississippi, USA, B) Nile, Egypt, C) Old abandoned Yellow (Huanghe) delta, China, D) Po, Italy E) Vistula, Poland, F) Shatt al Arab (Tigris-Euphrates), Iraq, G) Chao Phraya, Thailand, H) Ganges-Brahmaputra, Bangladesh, and I) Modern (since 1855) Yellow, China. Many areas are $<2 \mathrm{~m}$ above sea level (brown, yellow, pink). Scale bar on each image represents $50 \mathrm{~km}$. 


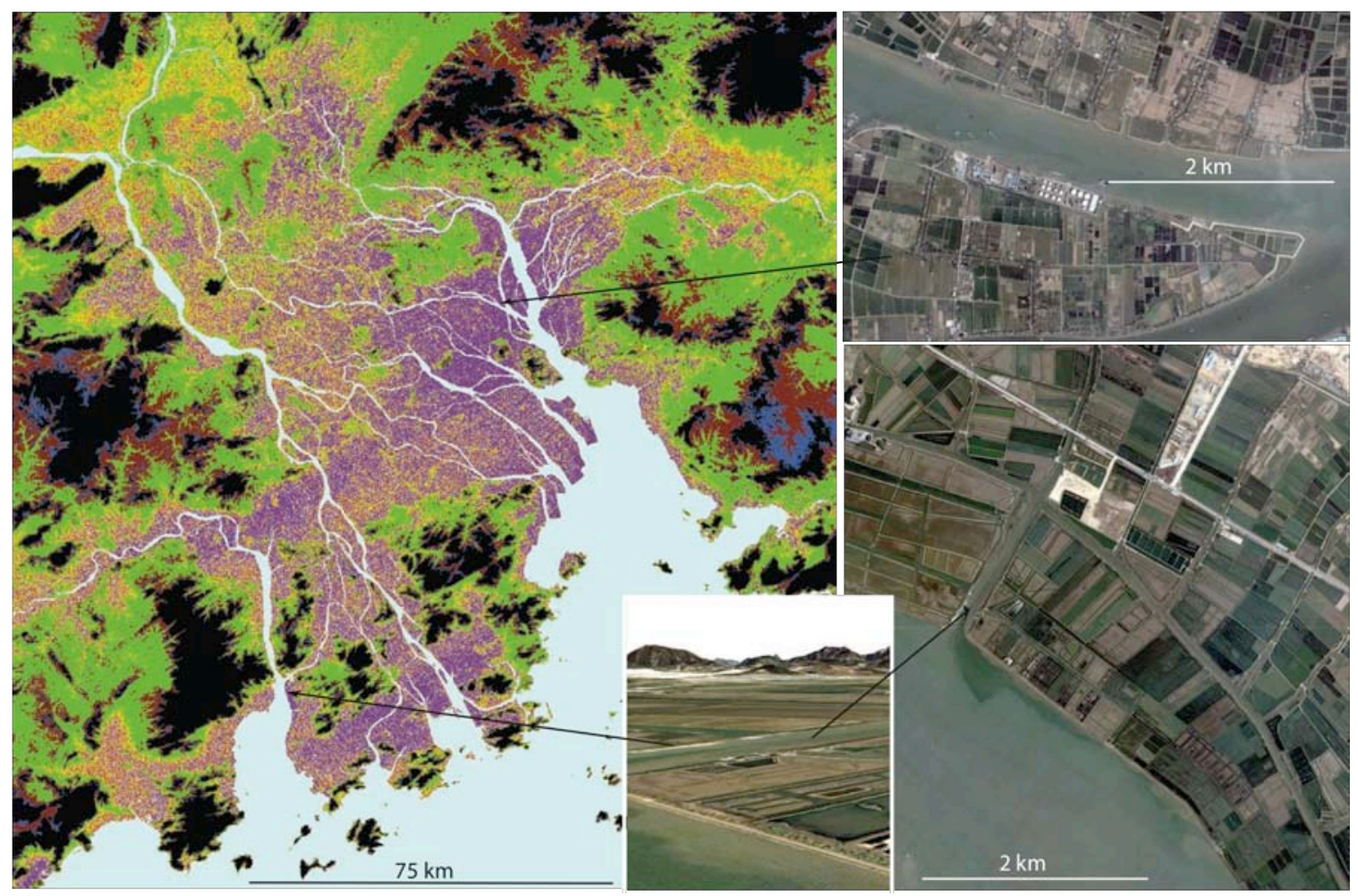

Figure 2: The Pearl delta, China, displayed with Space Shuttle Radar (SRTM) altimetry, binned as follows: purple $<0 \mathrm{~m}$, light blue $0 \mathrm{~m}$, brown $0-1 \mathrm{~m}$, light brown $1-2 \mathrm{~m}$, dark yellow 2-3m, light green 3-4m, yellow 4-5m, dark green 5-35m, dark brown $35-65 \mathrm{~m}$, dark blue $65-95 \mathrm{~m}$, and black $>95 \mathrm{~m}$. Delta portions below sea level are protected from storm surges by coastal and channel barriers as seen (B, C and D) in Digital Globe images served on Google Earth. 

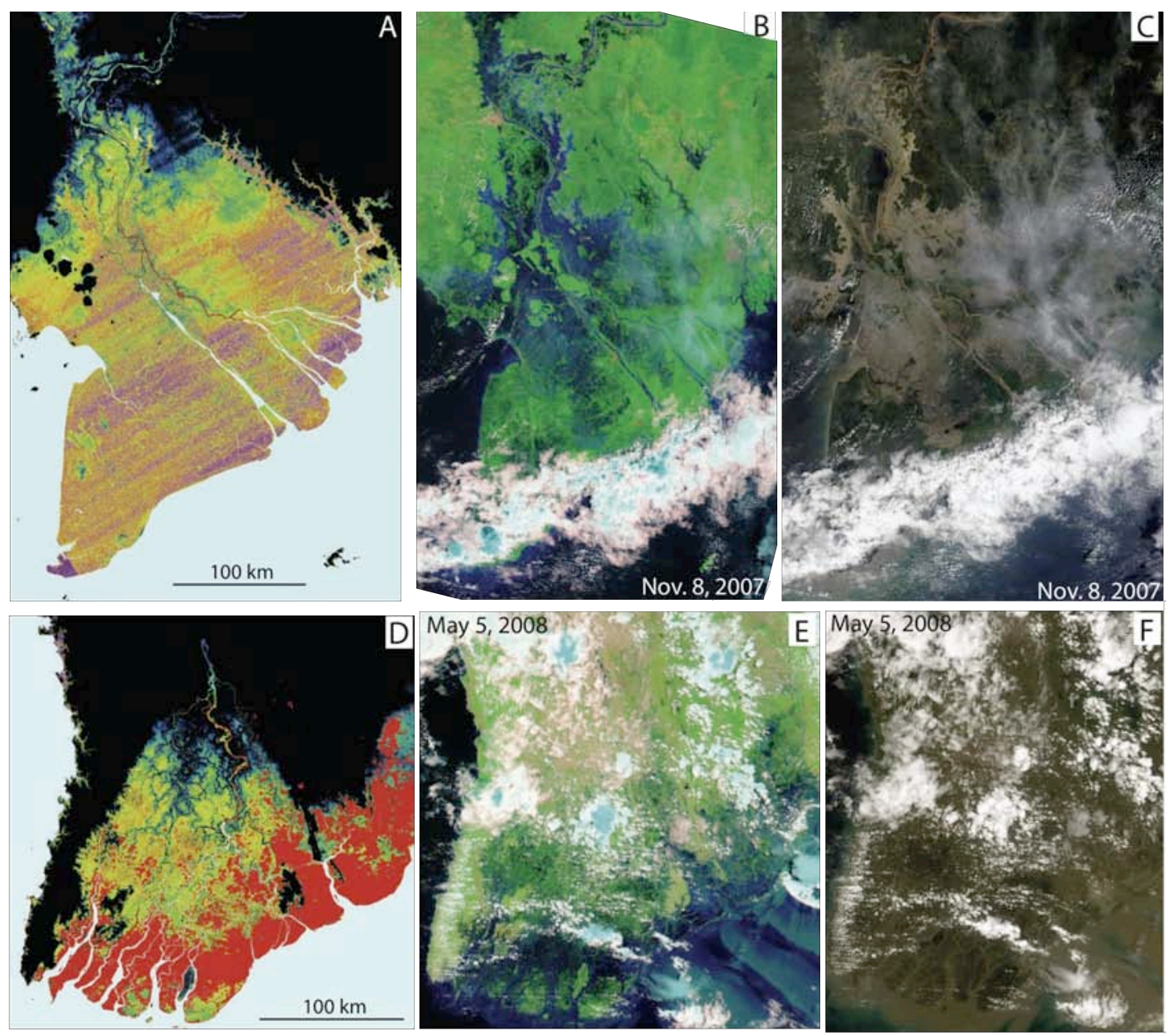

Figure 3: A) Mekong Delta, Vietnam, displayed with SRTM altimetry, binned at $1 \mathrm{~m}$ vertical intervals, starting at sea level (light blue), then 1 color per $1 \mathrm{~m}$ interval, to a height of $10 \mathrm{~m}$, then black. Topography below mean sea level is in shades of pink. B) MODIS near infrared image (Nov. 8, 2007), showing flooding of the upper Mekong Delta. C) MODIS true color imagery (Nov. 8, 2007) showing sediment laden floodwaters on the upper Mekong Delta. D) Flood waters shown in red, superimposed on SRTM altimetry. While delta has little area below mean sea level, the coastal surge from Cyclone Nargis was sufficient to drown a significant portion of the lower Irrawaddy delta. E) MODIS near infrared image (May 5, 2008), showing the flooding of the lower Irrawaddy delta caused by Cyclone Nargis. F) MODIS true color imagery (May 5, 2008), showing the sediment laden coastal waters. 

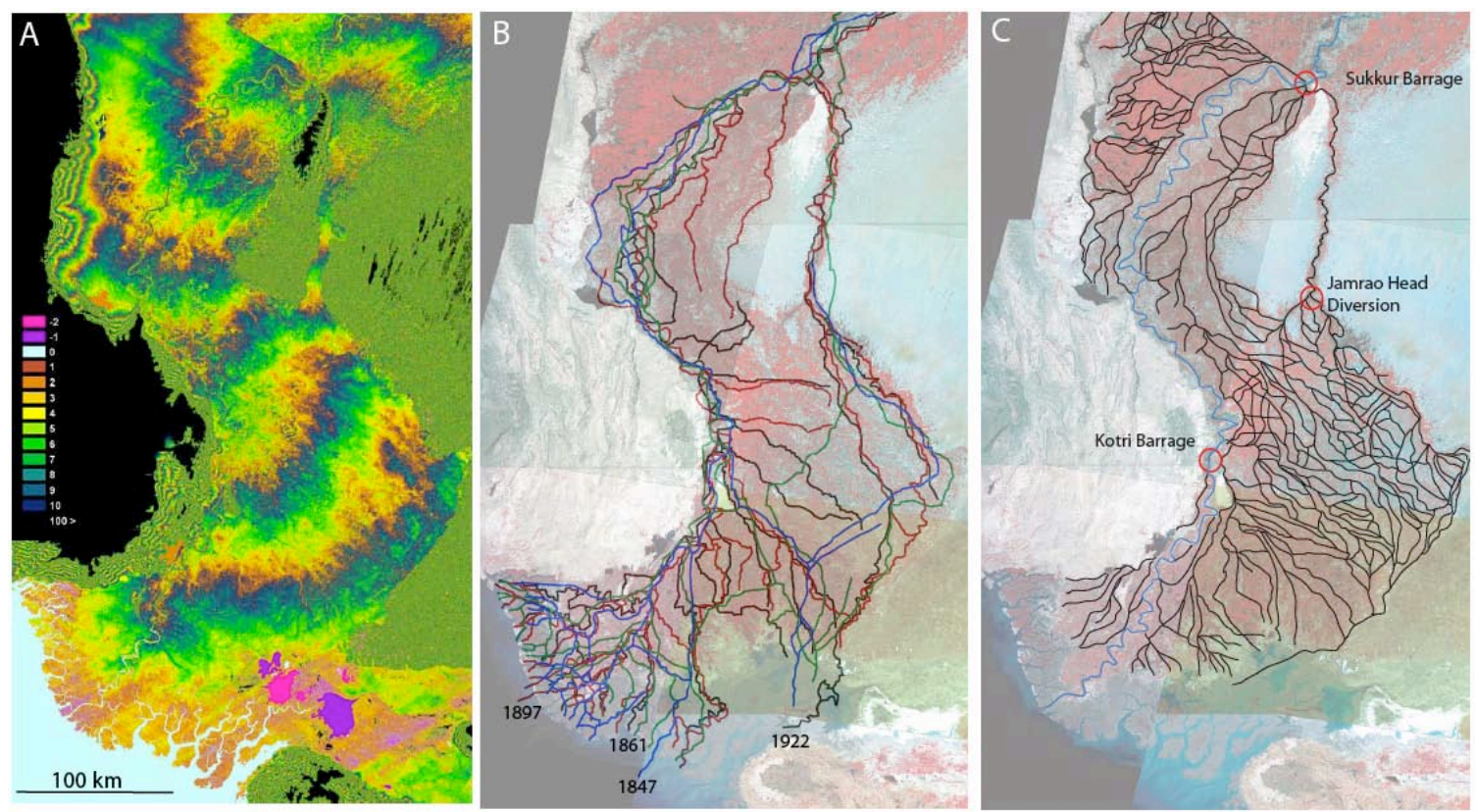

Figure 4: A) The Indus floodplain and Delta (Pakistan) displayed with SRTM altimetry, binned at $1 \mathrm{~m}$ vertical intervals, starting at sea level (light blue), then 1 color per $1 \mathrm{~m}$ interval, with colors cycled every $10 \mathrm{~m}$, to a height of $100 \mathrm{~m}$, then black. Topography below mean sea level is in shades of pink. B) 1) Historical location of distributary channels (cartographer, color, year and registration error): Weiland, blue, $1847, \pm 3.8 \mathrm{~km}$; Johnston, green, 1861, $\pm 3.8 \mathrm{~km}$; Rand McNally, red, 1897, $\pm 3.7 \mathrm{~km}$; and Bartholomew, black, 1922, $\pm 3.1 \mathrm{~km}$. C) Irrigation channel system with main water distribution stations. 